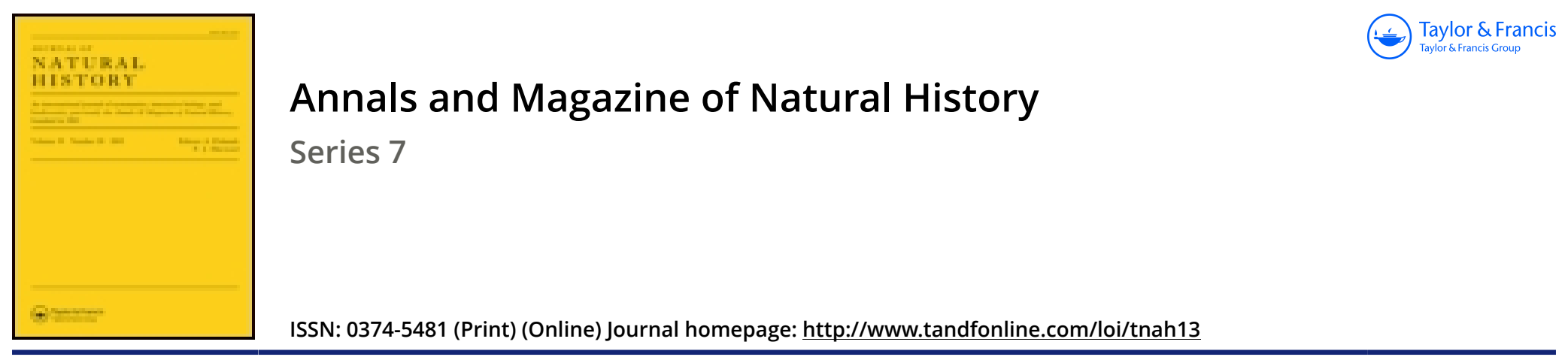

\title{
XIX.-On the squirrels of the Sciurus erythræus group
}

\section{J.L. Bonhote}

To cite this article: J.L. Bonhote (1901) XIX.—On the squirrels of the Sciurus erythræus group, Annals and Magazine of Natural History, 7:38, 160-167, DOI: 10.1080/00222930108678452

To link to this article: http://dx.doi.org/10.1080/00222930108678452

曲 Published online: 29 Sep 2009.

Submit your article to this journal $\pi$

Џ Article views: 3

Q View related articles $\longleftarrow$

Citing articles: 1 View citing articles 5 
The type specimens have been placed in the British Museum (Natural History).

\section{EXPLANATION OF PLATE III.}

Fig. 1. Hyperammina ramosissima, sp. n. $\times 15$ diam.

Fig. 2. Stacheia stomatifera, sp. n. $\times 10$ diam.

lig. 3. Syringopora serpens (Linné). Young specimen. $\times 15$ diam.

Fig. 4. Conchicolites tuberculifera, sp. n. $\times 12$ diam.

Fig. 5. Entrochus, gen. et sp. indet.; from side. $\times 8$ diam.

Fig. 6. The same form, upper end, showing joint-surface. $\times 8$ diam.

Fig. 7. Trochita, gen. et sp. indet.; joint-surface. $\times 20$ diam.

Figs. 8, 9. Trochite, gen. et sp. indet.; another form. Articular sturfaces, with ridges on fig. 8 , and grooves on fig. $9 . \times 20$ diam.

Fig. 10. Beyrichia muldensis, sp. n. $\times 45$ diam.

Fig. 11. Beyrichia tuberculata (Kloden), var. lineato-tuberculata, var, nov. $\times 30$ diam.

Fig. 12. Kloedenia gotlandica, sp. n. $a$, right valve, side view; $b$, edge view.

\section{XIX.-On the Squirrels of the Sciurus erythræus Group. By J. L. BONHOTE.}

THE squirrels of this group, though showing a considerable amount of variation and forming races which closely resemble each other, fall naturally into distinct groups, each group being restricted to its own locality.

The following remarks are based on the study of a very fair series at the National Museum, but several other species have been included, which are not there represented, to show what seems to be their proper relation to the group as a whole. I have been unable to make much mention of the skulls, chietly because the series of Indian skulls is rather deficient, and, as the skulls of these allied forms differ so slightly from each other, it is impossible to draw any deductions without a large series.

Five distinct species may be distinguished in this group, as woll as several geographical races :-

(i.) Sciurus erythraus, Pallas, from Assam, spreadingr through Bhutan, the Cachar Hills, and Manipur to Burma.

(ii.) Sciurus castaneoventris, Gray, from China, its range being from Ningpo to Burma, and possibly Assam.

(iii.) Sciurus Styani, 'Thos., between Ningpo and Shanghai.

(iv.) Sciurus thaiwanensis, sp. n., from Formosa.

(v.) Sciurus melunogaster, Thos., from Si-oban, Sipora. 
Before describing each race separately, it will perhaps be advisable to consider the chief specific differences:- $\$ c$. erythrceus, from India, is distinguished from all the other species by the absence of the fulvous tips to the hairs of the tail. Occasionally, in some of the other species, these tips, being very much worn, may not be conspicuous, but, as a rule, the Indian forms can by that character be immediately recognized. Sciurus melanogaster, with its black underparts, and Sc. Styani, with pale yellow underparts, are both easily distinguishable, while $S c$. castaneoventris may be known by its smaller size and the vinous tint of the underparts. Sc. thaiwanensis, from Formosa, may be recognized from Sc. erythroeus, the only species which it in any way resembles, by the fulvous tips to the hairs of the tail, which are more conspicuous in this species than in any of the others.

\section{Sciurus erythrous typicus, Pall.}

Sciurus erythraus, Pallas, Glires, p. 377 (1778) ; Gray, List Mamm. B. M. p. 142 (1843); Blyth, J. A. S. B. xxiv. p. 473 .

General colour above dark olive-brown, speckled with fulvous, each hair being dark at its base and having three or four fulvous annulations. Colour of underparts deep chestnut. Outside of limbs and head like the back, ears and tail like the underparts. The hairs of the tail are annulated like those of the back, but end in a long red tip, which, especially towards the end, entirely covers the annulations.

Hab. Assam.

There has been some doubt regarding which particular race Pallas's name should be applied to ; but as le distinctly states that the tail is of the same colour as the underparts, there can, I think, be little doubt that the Assam variety with the red tail is the one meant.

Sciurus erythraus lhutanensis, subsp. $\mathbf{n}$.

Macroxus erythrogaster, Blyth, Gray, Ann. \& Mag. Nat. Hist. xx. (1867) p. 282.

Sciurus erythreus, Blyth, J. A. S. B. xxiv. (1856) p. 473.

Closely resembles the foregoing, but the whole of the forehead is similar in colour to the underparts, while the hairs of the tail have short black ends, so that the tail is similar in colour to the back, with a black tip.

Hab. Bhutan.

Type, B.M. 43. 8. 18. 6. East India collection.

Gray (loc. cit.), in stating that Blyth's type of erythrogaster is from Bhutan and in the British Museum, refers 
without doubt to the specimen which has been chosen as the type of this species; he was, however, clearly mistaken, for Blyth, in the original description, gives Manipur as the typelocality, and according to Mr. W. Sclater * the type is at present in Calcutta.

\section{Sciurus erythrceus erythrogaster, Blyth.}

Sciurus erythrogaster, Blyth, J. A. S. B. xi. (1842) p. 970 ; id. op. cit. xxiv. (1856) p. 473.

Sciurus rufiventer, Blyth, J. A. S. B. xri. (1817) p. 871.

In this race, of which there is a fine series in the Museum, one may distinguish two distinct pelages.

In its summer pelage the general colour above is light yellowish grey, with an inclination to a warmer and browner tinge on the back, each hair being, as before, dark brown, with three or four annulations, and the general colour being caused by the predominance of these last. Ears yellowish; outer side of feet and tail as the back, the hairs at the tip of the latter being black to their bases, thus forming a black tip. Underparts as in preceding species.

In its winter pelage it is somewhat similar, except that the black ends to the hairs of the tail so predominate as to make the tail black, those hairs towards the tip being entirely devoid of annulations. A similar change, though not so complete, has taken place on the back, so that the general colour is of a dark steel-grey, minutely but profusely speckled with fulvous. Underparts as in summer, but, if anything, of a rather darker tint.

$H a b$. Manipur.

There is in the Museum a specimen from Assam which certainly agrees with Anderson's original description of Sc. Gordoni, var. intermedia $\dagger$; at first sight it closely resembles the present species in its summer pelage, but it possesses, however, the distinctive characters of Sc. castaneoventris from China, Sc. castaneoventris Gordoni, Anders., from Burma, being its nearest ally. It may be distinguished from the present species by the ears being similar in colour to the rest of the upper parts and by the nedian grizzled line below. Anderson further states that the hairs of the tail have fulvous ends and that the tail has no distinctive black subapical tip. These last characters, though not very well marked in the British Museum specimen, bring the race into the Sc. castaneoventris group.

* Cat. Mamm. Calc. Mus. p. 17 (1891).

+ Synonyin of Sc. griseopectus, Blyth (nec Gray), see later on. 
Sciurus erythreeus punctatissimus, Gray.

Sciurus punctatissimus, Gray, Ann. \& Mag. Nat. Hist. ser. 3, xx. (1867) p. 283.

Very similar to the winter pelage of erythrogaster, but the fulvous annulations much more minute, so that the general appearance is that of a black squirrel minutely speckled with fulvous. Uuderparts uniform deep chestnut. Tail black. Ears and feet like the upper parts.

Hab. Cachar Hills.

Type, B.M. 55. 12. 24. 108.

\section{Sciurus erythroeus Sladeni, Anders.}

Sciurus Sladeni, Anders. Proc. Zool. Soc. Lond. 1871, p. 139 ; Blyth, J. A. S. B. xliv. (1875) extr. no. p. 37 ; Anders. Zool. Res. (1880) p. 242.

This form, of which there are no specimens in the Museum, is evidently nearly related to the typical erythrous in having the red tip to the tail ; it is, however, quite distinct from all the other forms, and may be distinguished by its chestnut feet.

Hab. Thigyain, Upper Burma.

\section{Sciurus castaneoventris typicus.}

Sciurus castaneoventris, Gray, Ann. \& Mag. Nat. Hist. x. (1842) p. 263 ; Swinhoo, P. Z. S. 1870 , p. 623 .

General colour above brownish, each hair being of a greyish-brown, with three or four annulations of a lighter colour. Underparts vinaceous (rufous vinaceous of Ridgway), the colour being uniform and not broken by any median band. Tail like the back, each hair terminating in a fulvous end most conspicuous at the tip and sides of the tail.

$H a b$. 'The exact locality of the type is unknown, but all the other specimens in the Museum are from various places in the province of Fokien.

Type, B.M. 72 a. China (J.R. Reeves).

This species may always be distinguished from the foregoing by its smaller size, the fulvous ends to the hairs of the tail, and the vinaceous tint of the underparts.

Sciurus castaneoventris ningpoensis, subsp. $\mathrm{n}$.

This is a hill-form which is at present known only from the neighbourhood of Ningpo. 
It is distinguished by its much greyer coloration, caused by the annulations of the hairs being pale buff instead of fulvous or ruddy brown. Feet and limbs grey. Underparts uniform vinous.

Hab. Hills near Ningpo.

Type, B.M. 86. 10. 28. 3. Hills 30 miles from Ningpo, March 1884. Presented by Mr. F. W. Styan.

Sciurus castaneoventris Gordoni, Anders.

Sciurus Gordoni, Anders. P. Z. S. 1871, p. 140; Blyth, J. A. S. B. xliv. (1875) extr. no. p. 37.

This form differs from the typical Sc.castaneoventris by the presence of a median grizzled line running throughout the whole length of the underparts and by the vinaceous colour of the same being somewhat restricted on the flanks, thus forming two broad stripes.

$H a b$. Upper Burma.

\section{Sciurus castaneoventris griseopectus, Blyth.}

Sciurus griseopectus, Blyth (nec Gray), J. A. S. B. xvi. (1847) p. 873.

Sciurus Gordoni, var. intermedia, Anders. Zool. Res. (1879) p. 241.

This form is represented in the Museum by a single specimen only. It differs from Sc. Gordoni in the mesial grizzled line not being so broad or so well defined, and in the rufous portion of the -underparts being as broad as in the typical Sc. castaneoventris, but darker and richer in colour.

Hab. Assam.

My reasons for the inclusion of this form among the Sc. castaneoventris group have already been given, but it may be mentioned that the figure accompanying the original description is inaccurate in two important particulars, namely, the yellow ears and the black tip to the tail. With regard to the former, Blyth in his original description makes no mention of their colour, but he distinctly refers to the fulvous tips to the hairs of the tail.

Lest my divisions into species and subspecies may appear to some rather arbitrary, it will perhaps make it clearer if I point out that in Upper Burma and Assam we have two forms occurring in the same locality-namely, Sc. Gordoni and Sc. Sladeni in the former, and Sc.erythroeus and $S c$. griseopectus in the latter; it is therefore unlikely, though from the vagueness of the data not absolutely impossible, that these should all be geographical forms of one species, and this is further borne out, sufficiently to my mind to prove the 
existence of two species, by the evident affinity of $S c$. Gordoni to Sc.griseopectus and Sc. Sladeni to Sc.erythroeus, as well as the fact that the distinctive characters of the former are those of a widely distributed Chinese species. Mr. W. Sclater* mentions the type of griseopectus as being in the Calcutta Museum and coming from China. This locality has doubtless been placed on the specimen from its obvious affinity to the Chinese Sc. castaneoventris; but Blyth was himself ignorant of the exact locality, and as the specimen in the Museum agrees with his original description, we are, I think, justified, in default of further material, in assuming Assam to be its true habitat.

\section{Sciurus Styani, 'Thos.}

Macroxus yriseopectus, Gray, Ann. \& Mag. Nat. Hist. ser. 3, xx. (1867) p. 282 (nec Blyth).

Sciurus Styani, Thos. Ann. \& Mag. Nat. Hist. ser. 6, xiii. (1894) p. 363 ; de Winton, P.Z.S. 1899, p. 578.

Closely resembles Sc. castaneoventris, but may be dis-. tinguished by the very pale colour of the underparts, which are sometimes nearly white.

Hab. Yangtze Valley.

Type, B.M. 86. 10 28.5. Betwoen Shanghai and Hangchow, Dec. 1885 ( $F . W$. Styan).

Mr. de Winton has asked me to correct a note by Mr. Styan in his paper, quoted above, stating that probably Sc. Styani was identical with Gray's M. chinensis. 'I'he skull of Gray's type of chinensis has since been removed and it is evident that $M$. chinensis, which is a much smaller animal, has no connexion with the present group, but is allied to Sc. lokriah. The exact locality of Gray's type is also very vague, as Mr. Reeves, who procured it, collected over a large extent of country in India as well as in China.

Sciurus thaiwanensis, sp. n. (typiçal form).

Colour the same throughout and resembling Sc. erythrous erythrogaster (summer pelage), but slightly darker, each hair having two or three fulvous annulations and varying in colour from very dark brown on the back to greyish on the underparts. No red on the underparts, except, in some specimens, a tendency to a reddish patch at the base of the limbs. The outer margin of the ears is slightly lighter than the rest of the body. Tail grizzled for the first half of its length, then black, each hair having a long yellowish tip.

* W. Sclater, Cat. Mamm. Mus. Calc. (1891) p. 17. 
Dimensions (in flesh) :- Head and body 9 , tail 8 inches. Hab. South Formosa.

Type o ad., B.M. 94.11. 22. 5. Baksa, Formosa, 20th Oct., 1893. Collected by Mr. P. A. Holst.

Sciurus thaiwanensis centralis, subsp. $\mathbf{n}$.

Similar to the last, but having a narrow stripe of chestnut running from the inner side of each fore limb to the inner side of each corresponding hind limb.

Hab. Lak-ku-li, Formosa.

Type $q$ ad., B.M. 94. 11. 22. 4. Lak-ku-li, Formosa, 29th June, 1894. Collected by Mr. P. A. Holst.

This is evidently a hill-form inhabiting the Central Mountains.

\section{Sciurus thaiwanensis Roberti, subsp. $\mathrm{n}$.}

Sciurus erythreus, Swinhoe, P. Z. S. 1862, p. 357.

Similar to thaiwanensis typicus, but having the underparts of a rich deep chesnut and the general colour of the back darker and ruddier.

Hab. N.W. Formosa.

Type, B.M. 62. 12. 24. 13. N.W. Formosa (Robert Swinhoe).

Sciurus melanogaster, Thos.

Sciurus melanogaster, Thos. Ann. Mus. Genov. (2) xiv. p. 668 (1895).

A very dark species, above dark grizzled as in the preceding species; below very dark brown, interspersed with a few longer lightish hairs. Ears and feet sooty brown. Tail uniformly grizzled to its end. No fulvous tips to the hairs.

Dimensions (in flesh):-Head and body 200 , tail $17 \cdot 8$, hind foot 47, ear $17 \mathrm{~mm}$.

Hab. Si-oban, Sipora.

Co-type \&, B.M.95. 1.9.11. Si-oban, Sipora, July 1894. Presented by Dr. Modigliani.

Key to the Species.

A. Underparts deep chestnut.

$a^{1}$. Tail-hairs with no fulvous tips.

$a^{2}$. Tail with red tip.

$a^{3}$. Feet dark ................ Sc. erythraus typicus.

$b^{3}$. Feet chestnut

Sc. e. Sladeni.

$b^{2}$. Tail with black tip.

$a^{3}$. Forehead rufous ............ Sc. e. bhutanensis.

$b^{3}$. Forehend rufous $\ldots \ldots \ldots \ldots \ldots \ldots$ Sc. e. erythogaster

(summer). 
$c^{2}$. Tail black.

$c^{3}$. Annulations on hairs of back broad. Sc. e. erythogaster

$d^{3}$. Annulations on hairs of back narrow, Sc. e. punctatissimus.

$b^{\text {l }}$. Tail-hairs with fulvous tips.

$a^{2}$. Underparts uniformly coloured .... Sc. thaiwanensis Roberti.

$b^{2}$. Underparts with grizzled median line $\ldots \ldots \ldots \ldots \ldots \ldots \ldots \ldots$

B. Underparts same colour as the back .... Sc. $t$. centralis.

C. Underparts vinaceous (vinaceous rufous, Sc. t. typicus. Ridyway).

$a^{\mathbf{l}}$. Underparts uniformly coloured.

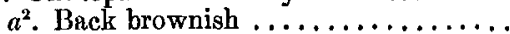

$b^{2}$. Back greyish $\ldots . . . . . . . . .$.

$b^{1}$. Underparts with grizzled median line.

$a^{2}$. Rufous area narrow $\ldots \ldots \ldots \ldots$.

$b^{2}$. Rufous area broad $\ldots \ldots \ldots \ldots \ldots$

D. Underparts yellow $\ldots \ldots \ldots \ldots \ldots \ldots \ldots$

E. Underparts black ...............

Sc. castaneoventris typicus.

Sc. c. ningpoensis.

Sc. c. Gordoni.

Sc. c. griseopectus.

Sc. Styani.

Sc. melanogaster.

\section{XX.-On the Squirrels of the Sciurus Prevostii Group. By J. L. Bonhote, B.A.}

ThIs group of squirrels, like the other groups with which I have already dealt, shows clearly that, although a certain amount of variation may be found in individuals from the same locality, yet when a large series comes to be examined there is no doubt as to the locality from which any particular individual may have come, and the differences, although in some instances slight, are in all cases constant. From the fact that the various races are geographical, it necessarily follows that there must be intermediate forms, and some of the races about to be described show this intergradation in a very marked degree.

For example Sciurus Caroli, described in this paper, is a very constant race and markedly distinct from Sciurus Caroli griseicauda, which, on the other hand, although constant in its essential characters, shows a wide range of individual variation.

Another point to be noted in regard to this paper is the case of Sciurus atricapillus from S.W. Borneo. 'There are no specimens in the Museum from that locality, so that one is unable to judge whether the differences between Sc. atricapillus and Sc. Caroli should entitle them to rank as species or subspecies. I have therefore described the latter as a new species, though the advent of further material may prove it to be only a subspecies of Sc. atricapillus. 